\title{
OPTIMASI FORMULA DAN STRUKTUR MIKROSKOPIK PASTA BEBAS GLUTEN BERBAHAN DASAR PUREE UBI JALAR UNGU DAN TEPUNG KACANG HIJAU
}

\author{
Formulation Optimization and Microscopic Structure of Gluten Free Pasta Based on \\ Purple Sweet Potato Puree and Mung Bean Flour \\ Ira Mulyawanti ${ }^{1,2}$, Slamet Budijanto ${ }^{3}$, Sedarnawati Yasni ${ }^{3}$ \\ 'Program Studi Ilmu Pangan, Sekolah Pascasarjana Institut Pertanian Bogor, \\ Jl. Raya Darmaga, Kampus IPB Darmaga, Bogor 16680 \\ ${ }^{2}$ Balai Besar Penelitian dan Pengembangan Pascapanen Pertanian, Jl. Tentara Pelajar No. 12, Bogor 16111 \\ ${ }^{3}$ Fakultas Teknologi Pertanian, Institut Pertanian Bogor, Kampus IPB Darmaga, PO Box 220, Bogor \\ Email: iramulyawanti@yahoo.com
}

\begin{abstract}
ABSTRAK
Penelitian bertujuan untuk mengoptimasi formula pasta bebas gluten berbahan dasar puree ubi jalar ungu dan tepung kacang hijau. Aplikasi mixture design dalam optimasi formula dapat menghasilkan formula yang optimal dengan karakteristik produk sesuai dengan yang diinginkan. Hasil penelitian menunjukkan bahwa komposisi optimal puree ubi jalar ungu dengan tepung kacang hijau dalam formula adalah 45,25\% puree ubi jalar ungu dan 51,75\% tepung kacang hijau. Pada komposisi tersebut dihasilkan pasta ubi jalar ungu dengan karakteristik yaitu kekenyalan 2,29 $\mathrm{mm}$, cohesiveness 0,38 , KKP 17,62\%, warna 333,48, $\mathrm{IC}_{50} 20,59 \%$, dan kandungan antosianin $42,42 \mathrm{mg} / \mathrm{L}$. Dari segi mikroskopik, pasta ubi jalar ungu matang dengan rasio puree ubi jalar ungu dengan formula di bawah $50 \%$ sudah menunjukkan adanya struktur yang kompak.
\end{abstract}

Kata kunci: Pasta, ubi jalar ungu, pangan bebas gluten, optimasi formula

\begin{abstract}
The aim of this study was to optimize gluten free pasta formula made from purple sweet potato puree and mung bean flour. Aplication of a mixture design allowed to find the optimal composition to achieve the desirable characteristic. The results showed that the optimal formula was mixture of $45.25 \%$ purple sweet potato puree and $51.75 \%$ mung bean flour. The characteristics of the chosen formula were springiness of $2.29 \mathrm{~mm}, 0.38$ cohesiveness, cooking loss $17.62 \%$, $333.48{ }^{\circ} \mathrm{Hue}, \mathrm{IC}_{50} 20.59 \%$, and $42.42 \mathrm{mg} / \mathrm{L}$ anthocyanin content. Microscopic structure showed that cooked pasta with purple sweet potato puree composition below $50 \%$ in the formula had a solid texture appearance.
\end{abstract}

Keywords: Pasta, purple sweet potatoes, gluten free food, formulation optimization

\section{PENDAHULUAN}

Ubi jalar ungu merupakan salah satu sumber karbohidrat lokal di Indonesia, yang juga memiliki nilai fungsional yang baik karena kandungan antosianinnya relatif tinggi. Kandungan rata-rata antosianin varietas ayamurazaki di dalam puree ubi jalar ungu yang dikukus lalu dikupas sebesar $480,45 \mathrm{mg} / \mathrm{L}$, dengan intensitas warna ungu yang paling dominan dan kapasitas antioksidan sebesar 3160,56 ppm AAE (Yasni dkk., 2009).

Pengembangan lanjut produk ubi jalar sebagai alternatif pangan pokok masih diteliti. Produk pasta berbahan dasar puree ubi jalar ungu merupakan satu alternatif yang memungkinkan. Pengolahan puree ubi jalar ungu menjadi produk pasta dapat dipilih karena teknologi dan peralatan yang dipergunakan cukup sederhana dan diharapkan dapat lebih mudah diterapkan di masyarakat. Tahapan proses yang cukup sederhana diharapkan masih dapat mempertahankan nilai fungsional ubi jalar ungu yaitu memiliki kandungan antosianin dan kapasitas antioksidan yang baik.

Kendala pada pengolahan produk pasta dengan puree ubi jalar ungu adalah tidak memiliki kandungan gluten yaitu protein yang bersifat khas yang terdapat pada tepung terigu dan berfungsi dalam pembentukan tekstur pasta. Formulasi pasta bebas gluten salah satunya dapat dilakukan dengan menambahkan protein, gum, dan atau emulsifier yang bertindak 
sebagai pengganti gluten (Marti dan Pagani, 2013). Pengolahan pasta ubi jalar dengan konsep pasta bebas gluten telah diteliti, diantaranya oleh Limroongreungrat dan Huang (2007) dan Gopalakrishnan dkk. (2011). Pada pengolahan pasta bebas gluten dari ubi jalar pada kedua penelitian tersebut diketahui adanya penambahan sumber protein sebagai substitusi gluten yang tidak dimiliki oleh ubi jalar. Limroongreungrat dan Huang (2007) menambahkan tepung kedelai dan isolat protein kedelai sebagai sumber protein ke dalam formula pasta ubi jalar. Gopalakrishnan dkk. (2011) membuat pasta dari ubi jalar dengan menambahkan sumber protein seperti Whey Protein Concetrate (WPC), defatted soy flour (DSF), dan tepung ikan ke dalam formulanya. Hasil penelitian tersebut menunjukkan bahwa secara struktur morfologi menggunakan Scanning Electron Microscopy (SEM), penggunaan WPC menghasilkan formasi matrik protein-pati yang paling kuat dibandingkan dengan penambahan DSF dan tepung ikan. Pembentukan matrik protein pati yang kuat diperlukan dalam pembuatan pasta bebas gluten untuk menekan terjadinya kehilangan karena pemasakan yang tinggi sehingga keutuhan produk saat dimasak dapat dipertahankan.

Kacang hijau merupakan salah satu jenis kacangkacangan yang memiliki kandungan protein yang cukup tinggi dan patinya mengandung amilosa tinggi. Kandungan amilosa yang tinggi pada tepung kacang hijau dibutuhkan dalam pembentukan tekstur pasta karena dapat membentuk struktur gel yang lebih kompak. Karakteristik dari tepung kacang hijau tersebut dan komposisi optimalnya di dalam formula diharapkan dapat membentuk adonan yang baik pada produk pasta. Hal ini berkaitan dengan pembentukan matrik protein pati yang terbentuk, dimana strukturnya dapat dilihat melalui teknik Scanning Electron Microscopy (SEM).

Dari uraian di atas, untuk membuat pasta bebas gluten dari ubi jalar ungu diperlukan upaya formulasi. Tujuan penelitian ini adalah melakukan optimasi komposisi puree ubi jalar ungu dengan penambahan tepung kacang hijau dalam formula pasta ubi jalar ungu sehingga diperoleh produk pasta yang secara fisik baik dan memiliki nilai fungsional, serta mengetahui struktur produk pasta secara mikroskopik.

\section{METODE PENELITIAN}

\section{Tempat dan Waktu}

Penelitian dilakukan pada bulan Maret-Desember 2014 di Laboratorium Balai Besar Penelitian dan Pengembangan Pascapanen Pertanian, Kementerian Pertanian dan SEAFAST Center-IPB.

\section{Bahan dan Alat}

Bahan baku yang digunakan dalam penelitian adalah ubi jalar ungu yang diperoleh dari Balai Penelitian Kacang-
Kacangan dan Umbi-Umbian (BALITKABI), Malang-Jawa Timur. Kacang hijau, dan tepung tapioka yang diperoleh dari pasar Bogor. Bahan kimia yang digunakan dalam penelitian diantaranya $\mathrm{KCl}, \mathrm{Na}$-asetat, asam tartarat, DPPH, dan etanol.

Alat-alat yang digunakan untuk proses pengolahan pasta diantaranya food processor, ekstruder, pengukus, dan pengering tipe rak. Alat-alat yang digunakan untuk analisa diantaranya spektrofotometer (UV 6500 Spectrophotometer A KRUSS Optronic Germany), shaker, timbangan analitik, texture analyzer (Texture Pro CT 3 Brookfield), chromameter (CR 300 Minolta), Scanning Electron Microscopy (SEM) dan alat-alat gelas lainnya.

\section{Metode}

Penelitian yang dilakukan meliputi optimasi formula pada pengolahan pasta ubi jalar ungu dan analisis struktur mikroskopik produk.

\section{Optimasi Formula pada Proses Pembuatan Pasta}

Optimasi formula dilakukan berdasarkan mixture D-optimal design dengan menggunakan bantuan perangkat lunak Design Expert DX 7. Tahapan optimasi meliputi percobaan pendahuluan, rancangan formula dan analisis respon, optimasi, dan verifikasi. Percobaan pendahuluan dilakukan untuk menetapkan batas atas dan batas bawah porsi puree ubi jalar ungu yang akan di-input ke dalam program. Penentuan batas atas dan bawah didasarkan pada jumlah maksimal dan minimal puree ubi jalar ungu dalam formula yang masih dapat menghasilkan produk pasta yang baik berdasarkan respon kekenyalan ( $\mathrm{mm})$, cohesiveness, kehilangan karena pemasakan (KKP (\%)), dan warna $\left({ }^{\circ} \mathrm{Hue}\right)$. Hasil input batas atas dan bawah tersebut menghasilkan rancangan formula. Selain dilakukan input batas atas dan bawah puree ubi jalar ungu, dilakukan pula input respon yang akan dianalisis. Respon yang di-input ke dalam program meliputi kekenyalan, cohesiveness, warna, kehilangan karena pemasakan (KKP), aktivitas antioksidan, antosianin. Respon-respon tersebut dipilih karena dinilai bahwa akan berubah dengan adanya perbedaan komposisi puree ubi jalar ungu dengan tepung kacang hijau di dalam formula. Pada tahap optimasi, akan diperoleh formula solusi yang dipilih berdasarkan nilai desirability terbesar. Setelah diperoleh formula solusi atau formula optimum dilanjutkan dengan melakukan verifikasi. Aplikasi tersebut dapat menghasilkan komposisi optimal formula yang menghasilkan karakteristik yang diinginkan (Larossa dkk., 2013).

Proses pembuatan pasta ubi jalar ungu diawali dengan persiapan bahan baku yaitu meliputi pembuatan puree ubi jalar ungu dan pembuatan tepung kacang hijau. Puree ubi jalar ungu diperoleh melalui tahapan yaitu ubi jalar ungu 
disortasi, dibersihkan, dikukus menggunakan pengukus selama 45 menit, didinginkan, dikupas kulitnya, kemudian dibuburkan dengan menggunakan food processor, dikemas, dan disimpan di dalam freezer sampai digunakan. Tepung kacang hijau diperoleh dengan menepungkan kacang hijau beserta kulitnya dengan alat penepung, kemudian disaring menggunakan saringan 80 mesh. Proses pembuatan pasta ubi jalar ungu dilakukan melalui tahapan yaitu puree ubi jalar ungu dicampur dengan tepung tapioka dan tepung kacang hijau, diaduk, diuleni hingga tercampur merata. Adonan yang sudah tercampur merata kemudian dikukus selama 15 menit, dilanjutkan dengan pengadukan selama 2 menit. Adonan kemudian dicetak menggunakan ekstruder (mesin mi multifungsi). Pasta yang sudah dibentuk kemudian dikeringkan dengan pengering tipe rak pada suhu $50^{\circ} \mathrm{C}$ selama 10 jam.

\section{Analisis Struktur Mikroskopik Pasta (Gopalakrishnan dkk., 2011)}

Struktur mikroskopik pasta ubi jalar ungu yang sudah dimasak dilihat dengan teknik Scanning electron microscopy (SEM). Pasta ubi jalar ungu matang dipotong secara vertikal, kemudian dihilangkan airnya dengan cara direndam dalam etanol 35\%, 50\%, 75\%, 95\%, dan 100\% secara bertahap masing-masing selama 30 menit, kemudian dilanjutkan dengan proses pengeringan menggunakan alat Critical Point Dryer. Sampel yang sudah kering kemudian dilapisi dengan emas dan diamati morfologi permukaannya dengan menggunakan alat Scanning Electron Microscopy pada perbesaran 500 dan 2500 kali.

\section{HASIL DAN PEMBAHASAN}

\section{Optimasi Formula pada Proses Pembuatan Pasta Percobaan Pendahuluan}

Percobaan pendahuluan dilakukan untuk menentukan batas atas dan batas bawah puree ubi jalar ungu yang dapat diformulasikan ke dalam formula. Hasil formulasi awal pembuatan produk pasta ubi jalar ungu menunjukkan karakteristik produk seperti disajikan pada Tabel 1.

Produk pasta dengan rasio puree ubi jalar ungu dan tepung kacang hijau 70:27 menghasilkan produk pasta yang sangat rapuh saat pemasakan, dengan waktu pemasakan yang sangat singkat. Pada rasio puree ubi jalar ungu dan tepung kacang hijau 60:37 pasta ubi jalar ungu masih dapat dipertahankan bentuknya walaupun memiliki waktu pemasakan optimal yang relatif singkat. Hasil analisis juga menunjukkan bahwa kekenyalan dan cohesiveness pasta semakin besar dengan semakin rendahnya rasio puree ubi jalar ungu di dalam formula. Hal ini dijumpai pula pada penelitian sebelumnya yang menerangkan bahwa terjadi korelasi yang positif antara nilai kekenyalan dan cohesiveness (Limroongreungrat dan Huang, 2007). Rasio kacang hijau yang semakin tinggi dalam formula menyebabkan semakin tingginya kandungan protein dalam formula, dengan demikian terjadi ikatan yang semakin baik antara pati dengan protein yang membentuk matrik yang lebih kokoh dan kompak. Selain tekstur, nilai KKP merupakan salah satu karakteristik fisik pasta yang menentukan kualitas pasta masak. Nilai KKP menunjukkan banyaknya padatan yang terlarut dalam air selama pemasakan. Sedikitnya jumlah padatan yang larut dalam air selama pemasakan mengindikasikan kualitas pasta yang baik. Namun demikian, penelitian-penelitian yang sudah ada menjelaskan bahwa nilai KKP pada pasta bebas gluten atau rendah gluten cenderung memiliki nilai KKP yang lebih tinggi dibandingkan dengan nilai KKP pasta dari terigu (Ho dan Athapol, 2011; Lucisano dkk., 2012; Susanna dan Prabasankar, 2013). KKP produk menunjukkan rasio puree ubi jalar ungu dengan tepung kacang hijau 40:57 memberikan nilai terkecil, yaitu $17,09 \%$.

Produk memiliki kisaran warna $2,7-45,21^{\circ} \mathrm{H}$ yang berada pada kisaran warna merah keunguan. Intensitas warna ungu semakin besar dengan semakin besarnya rasio ubi jalar ungu di dalam formula. Berdasarkan karakteristik produk yang dihasilkan dari formulasi awal ditetapkan batas atas

Tabel 1. Karakteristik pasta ubi jalar ungu

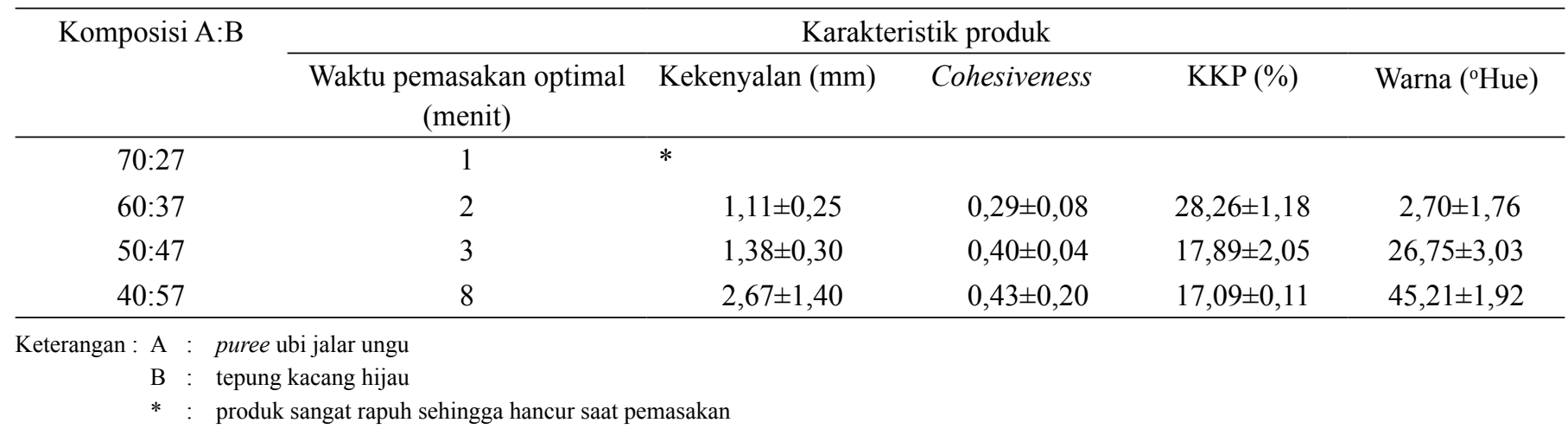


puree ubi jalar ungu di dalam formula adalah sebanyak $60 \%$ dan batas bawahnya adalah $40 \%$.

\section{Rancangan Formula dan Analisis Respon}

Optimasi formula dilakukan dengan bantuan perangkat lunak DX 7. Berdasarkan batas atas dan batas bawah yang telah ditentukan pada formulasi awal, diperoleh rancangan formula beserta responnya seperti disajikan pada Tabel 2 .

Hasil penelitian menunjukkan bahwa secara fisik, karakteristik pasta ubi jalar ungu lebih baik dengan semakin rendahnya rasio puree ubi jalar ungu di dalam formula. Sebaliknya pasta ubi jalar ungu memiliki nilai fungsional yang semakin baik dengan semakin tingginya rasio ubi jalar ungu di dalam formula (Tabel 2).

Profil tekstur pasta ubi jalar ungu dinyatakan dalam respon kekenyalan dan cohesiveness. Produk pasta ubi jalar ungu memiliki tingkat kekenyalan dan cohesiveness yang semakin rendah dengan penggunaan puree ubi jalar ungu yang semakin tinggi dalam formula (Tabel 2), yaitu ditunjukkan dengan konstanta yang bernilai negatif dalam persamaan polinomial (Tabel 3). Selain itu, tingginya rasio puree ubi jalar ungu dalam formula juga menyebabkan nilai KKP produk yang semakin tinggi. Nilai KKP pasta yang dihasilkan berkisar antara rentang nilai 11,04-30,39\%, yang menunjukkan cukup tinggi dan menggambarkan lemahnya ikatan protein pati yang terbentuk. Hal ini ditemui pula pada penelitian sebelumnya yang menjelaskan bahwa pada produk pasta ubi jalar yang diperkaya dengan tepung protein ikan, serta masih mengandung 27\% tepung terigu dalam formulanya, memiliki nilai KKP pada rentang $12-16 \%$ (Gopalakrishnan dkk., 2011). Nilai kekenyalan, cohesiveness dan KKP dipengaruhi oleh kekuatan matrik protein pati yang terbentuk selama proses pembuatan pasta. Selama pemasakan, granula pati akan membengkak dan akan cenderung pecah sehingga sebagian akan larut. Protein yang tidak larut akan cenderung menggumpal membentuk jaringan kuat yang dapat memerangkap pati. Semakin cepat terjadinya pembentukan jaringan protein, pembengkakan pati akan semakin kecil, sehingga konsistensi produk akan semakin baik dan pasta menjadi tidak lengket (Marti dan Pagani, 2013). Hal ini dipengaruhi karena selain memiliki kandungan protein yang cukup tinggi, pati kacang hijau memiliki kadar amilosa yang cukup tinggi pula dengan profil viscoamylogram pasting tipe $\mathrm{C}$, yaitu ditandai dengan adanya puncak dan peningkatan viskositas yang konstan selama pengadukan dan pemanasan, sehingga cukup baik dijadikan salah satu bahan baku untuk pembuatan pasta (Marti dan Pagani, 2013).

Namun demikian rendahnya rasio puree ubi jalar ungu di dalam formula akan menghasilkan produk dengan nilai fungsional yang semakin rendah, yaitu aktivitas antioksidan dan kandungan antosianin yang rendah. Rendahnya kandungan antosianin dalam formula juga mempengaruhi warna produk pasta menjadi lebih dominan merah, yaitu merah keuanguan. Variasi warna dan kandungan antosianin berkorelasi dengan

Tabel 2. Profil kekenyalan, cohesiveness, warna, $\mathrm{KKP}, \mathrm{IC}_{50}$, dan antosianin pasta ubi jalar ungu pada formula yang diperoleh berdasarkan mixture D-optimal design

\begin{tabular}{|c|c|c|c|c|c|c|c|c|}
\hline \multirow{2}{*}{ Formula } & \multicolumn{2}{|c|}{$\begin{array}{c}\text { Proporsi komposisi bahan } \\
(\%)\end{array}$} & \multicolumn{6}{|c|}{ Respon } \\
\hline & $\begin{array}{l}\text { Puree ubi } \\
\text { jalar ungu }\end{array}$ & $\begin{array}{c}\text { Tepung } \\
\text { kacang hijau }\end{array}$ & $\begin{array}{l}\text { Kekenyalan } \\
(\mathrm{mm})\end{array}$ & Cohesiveness & $\begin{array}{l}\text { Warna } \\
\left({ }^{0} \mathrm{H}\right)\end{array}$ & $\begin{array}{c}\text { KKP } \\
(\%)\end{array}$ & $\begin{array}{l}\text { IC50 } \\
(\%)\end{array}$ & $\begin{array}{l}\text { Antosia-nin } \\
(\mathrm{mg} / \mathrm{L})\end{array}$ \\
\hline 1 & 45,04 & 51,96 & 4,14 & 0,43 & 338,18 & 16,35 & 19,33 & 42,42 \\
\hline 2 & 57,48 & 39,52 & 1,06 & 0,33 & 333,56 & 18,75 & 11,68 & 77,73 \\
\hline 3 & 60,00 & 37,00 & 0,78 & 0,39 & 328,41 & 28,43 & 10,57 & 104,54 \\
\hline 4 & 60,00 & 37,00 & 0,13 & 0,33 & 329,5 & 30,39 & 10,21 & 107,62 \\
\hline 5 & 42,52 & 54,48 & 2,66 & 0,48 & 334,15 & 17,18 & 38,74 & 40,08 \\
\hline 6 & 52,44 & 44,56 & 1,37 & 0,29 & 326,03 & 19,70 & 20,00 & 41,75 \\
\hline 7 & 50,00 & 47,00 & 2,52 & 0,33 & 333,19 & 16,36 & 28,52 & 52,10 \\
\hline 8 & 54,96 & 42,04 & 1,21 & 0,42 & 322,94 & 27,15 & 13,53 & 56,78 \\
\hline 9 & 40,00 & 57,00 & 3,58 & 0,46 & 337,42 & 11,04 & 69,56 & 33,62 \\
\hline 10 & 60,00 & 37,00 & 0,91 & 0,28 & 327,43 & 28,00 & 12,91 & 100,54 \\
\hline 11 & 40,00 & 57,00 & 1,88 & 0,50 & 338,33 & 13,43 & 55,67 & 29,56 \\
\hline 12 & 40,00 & 57,00 & 1,74 & 0,46 & 343,33 & 17,90 & 66,45 & 35,34 \\
\hline 13 & 50,00 & 47,00 & 1,16 & 0,44 & 334,04 & 15,51 & 43,10 & 54,52 \\
\hline
\end{tabular}


Tabel 3. Hasil analisis respon optimasi formula pasta ubi jalar ungu

\begin{tabular}{|c|c|c|c|c|c|c|c|c|}
\hline \multirow[b]{2}{*}{ Respon } & \multirow[b]{2}{*}{ Model } & \multicolumn{3}{|c|}{ p-value } & \multirow[b]{2}{*}{$\begin{array}{c}\text { Adj } \\
\mathrm{R}^{2}\end{array}$} & \multirow[b]{2}{*}{$\begin{array}{l}\text { Pred. } \\
\mathrm{R}^{2}\end{array}$} & \multirow{2}{*}{$\begin{array}{c}\text { Adeq. } \\
\text { Precision }\end{array}$} & \multirow[b]{2}{*}{ Persamaan polinomial } \\
\hline & & Model & $\begin{array}{l}\text { Lack of } \\
\text { Fit }\end{array}$ & $\mathrm{R}^{2}$ & & & & \\
\hline Kekenyalan & Linier & $\begin{array}{l}<0,0001 \\
\text { Sig }\end{array}$ & $\begin{array}{l}0,0518 \\
\text { Not sig }\end{array}$ & 0,5383 & 0,4963 & 0,3540 & 6,595 & $-0.032831 \mathrm{~A}+0.073223 \mathrm{~B}$ \\
\hline Cohesiveness & Linier & $\begin{array}{l}0,0016 \\
\text { Sig }\end{array}$ & $\begin{array}{l}0,5970 \\
\text { Not sig }\end{array}$ & 0,6122 & 0,5769 & 0,4909 & 7,674 & $\begin{array}{l}+5,324 \\
\mathrm{x} 10^{-4} \mathrm{~A}+7,87542 \times 10^{-3} \mathrm{~B}\end{array}$ \\
\hline Warna & Linier & $\begin{array}{l}0,0015 \\
\text { Sig }\end{array}$ & $\begin{array}{l}0,0554 \\
\text { Not sig }\end{array}$ & 0,6166 & 0,5817 & 0,4871 & 7,745 & $+3,158 \mathrm{~A}+3,723 \mathrm{~B}$ \\
\hline KKP & Linier & $\begin{array}{l}0,0003 \\
\text { Sig }\end{array}$ & $\begin{array}{l}0,1021 \\
\text { Not sig }\end{array}$ & 0,7066 & 0,6800 & 0,5936 & 9,48 & $+0,52679 \mathrm{~A}-0,13723 \mathrm{~B}$ \\
\hline $\begin{array}{l}\text { Aktivitas } \\
\text { Antioksidan }\end{array}$ & Linier & $\begin{array}{l}<0,0001 \\
\text { Sig }\end{array}$ & $\begin{array}{l}0,0730 \\
\text { Not sig }\end{array}$ & 0,7760 & 0,7560 & 0,694 & 11,363 & $-0,839 \mathrm{~A}+1,558 \mathrm{~B}$ \\
\hline Antosianin & Kubik & $\begin{array}{l}<0,0001 \\
\text { Sig }\end{array}$ & $\begin{array}{l}0,0602 \\
\text { Not sig }\end{array}$ & 0,9773 & 0,9697 & 0,9554 & 26,385 & $\begin{array}{l}38,39 \mathrm{~A}-33,95 \mathrm{~B}-0,072 \mathrm{AB}- \\
0,015 \mathrm{AB}(\mathrm{A}-\mathrm{B})\end{array}$ \\
\hline
\end{tabular}

Keterangan: $\mathrm{A}=$ puree ubi jalar ungu; $\mathrm{B}=$ tepung kacang hijau

parameter kromatis dan dapat mengindikasikan bahwa pengukuran warna dapat digunakan untuk memperkirakan kandungan antosianin (Alighourchi dan Mohsen, 2009).

Analisis respon produk pasta ubi jalar ungu menghasilkan model yang signifikan untuk semua respon, yaitu $\mathrm{p}<0,05(\mathrm{p}<0,001)$ dan lack of fit yang tidak signifikan $\mathrm{p}>0,05$. Nilai lack of fit yang tidak signifikan adalah syarat untuk model yang baik, karena menunjukkan adanya kesesuaian data respon dengan model. Predicted $\mathrm{R}^{2}$ dan adjusted $\mathrm{R}^{2}$ menunjukkan data-data yang diprediksi dan datadata aktual untuk setiap respon. Hasil analisis menunjukkan bahwa selisih nilai predicted $\mathrm{R}^{2}$ dengan adjusted $\mathrm{R}^{2}$ kurang dari 0,2 untuk semua respon, hal ini berarti bahwa nilai predicted $\mathrm{R}^{2}$ mendukung adjusted $\mathrm{R}^{2}$. Adequate precision menunjukkan besarnya sinyal terhadap noise ratio. Semua respon menunjukkan nilai adequate precision lebih besar dari 4, hal tersebut mengindikasikan sinyal yang memadai sehingga model dapat digunakan sebagai design space.

\section{Optimasi}

Optimasi dilakukan untuk memperoleh satu formula dimana memiliki komposisi puree ubi jalar ungu dengan tepung kacang hijau yang tepat sehingga diperoleh produk yang diinginkan dan memiliki respon optimal. Dalam proses optimasi dilakukan pembobotan untuk setiap komponen dan respon. Pembobotan dilakukan berdasarkan kepentingannya pada produk yang dihasilkan, dalam hal ini produk pasta ubi jalar ungu yang karakteristiknya baik secara fisik dan memiliki nilai fungsional bagi kesehatan, yaitu ditandai dengan kandungan antosianin dan aktivitas antioksidan yang tinggi (Tabel 4).
Tabel 4. Kriteria optimasi formula pasta ubi jalar ungu

\begin{tabular}{lcccc}
\hline Komponen dan respon & \multicolumn{4}{c}{ Kriteria } \\
\cline { 2 - 5 } & Goal & $\begin{array}{c}\text { Batas } \\
\text { bawah }\end{array}$ & $\begin{array}{c}\text { Batas } \\
\text { atas }\end{array}$ & Importance \\
\hline Komponen & & & \\
Puree ubi jalar ungu (\%) & in range & 40 & 60 & \\
Tepung kacang hijau (\%) & in range & 37 & 57 & \\
\hline Respon & & & & \\
Kekenyalan (mm) & Maximize & 0,13 & 4,14 & ++++ \\
Cohesieness & Maximize & 0,28 & 0,50 & ++++ \\
Warna $\left({ }^{0} \mathrm{H}\right)$ & In range & 322,94 & 343,33 & +++ \\
KKP $(\%)$ & Minimize & 15,51 & 30,39 & +++++ \\
Aktivitas antioksidan (\%) & Minimize & 10,21 & 69,56 & +++++ \\
Antosianin $(\mathrm{mg} / \mathrm{L})$ & Maximize & 29,56 & 107,62 & +++++ \\
\hline
\end{tabular}

Kekenyalan, cohesiveness, dan antosianin ditargetkan menghasilkan goal maximize. Kekenyalan dan cohesiveness merupakan parameter karakteristik fisik pasta yang menentukan tekstur, dimana nilai kekenyalan dan cohesiveness yang semakin tinggi menunjukkan karakteristik tekstur pasta yang semakin baik. Sedangkan antosianin merupakan pigmen alami yang terkandung di dalam puree ubi jalar ungu yang juga berfungsi sebagai antioksidan. Semakin tinggi kandungan antosianin dalam produk merupakan indikasi nilai fungsional produk yang semakin baik. Warna, KKP, dan kapasitas antioksidan ditargetkan menghasilkan goal minimize. Warna mengindikasikan kandungan antosianin dalam produk pasta yang dihasilkan dan dinyatakan dalam nilai Hue $\left({ }^{\circ} \mathrm{H}\right)$. Warna juga mempengaruhi visualisasi produk yang dihasilkan. Target untuk respon warna adalah in range karena dianggap 
warna yang dihasilkan dalam kisaran warna ungu hingga merah keunguan masih dapat diterima oleh konsumen. KKP menunjukkan kekompakan produk yang dihasilkan. Nilai KKP akan semakin besar dengan semakin tingginya tingkat kehilangan padatan akibat larut dalam air selama proses pemasakan, yang ditandai dengan semakin keruhnya air. Untuk itu, goal yang diinginkan untuk nilai KKP dalam optimasi adalah minimize. Aktivitas antioksidan dinyatakan dengan $\mathrm{IC}_{50}$. Semakin kecil nilai $\mathrm{IC}_{50}$ mengindikasikan aktivitas antioksidan yang semakin tinggi, sehingga goal yang diinginkan adalah minimize. Hasil optimasi diperoleh satu formula solusi dengan komposisi puree ubi jalar ungu $45,25 \%$ dan tepung kacang hijau 51,75\%, dengan nilai desirability 0,923 (Gambar 2). Dengan nilai desirability tersebut, formula dapat menghasilkan produk yang memiliki karakteristik sesuai target optimasi sebesar 92,3\%.

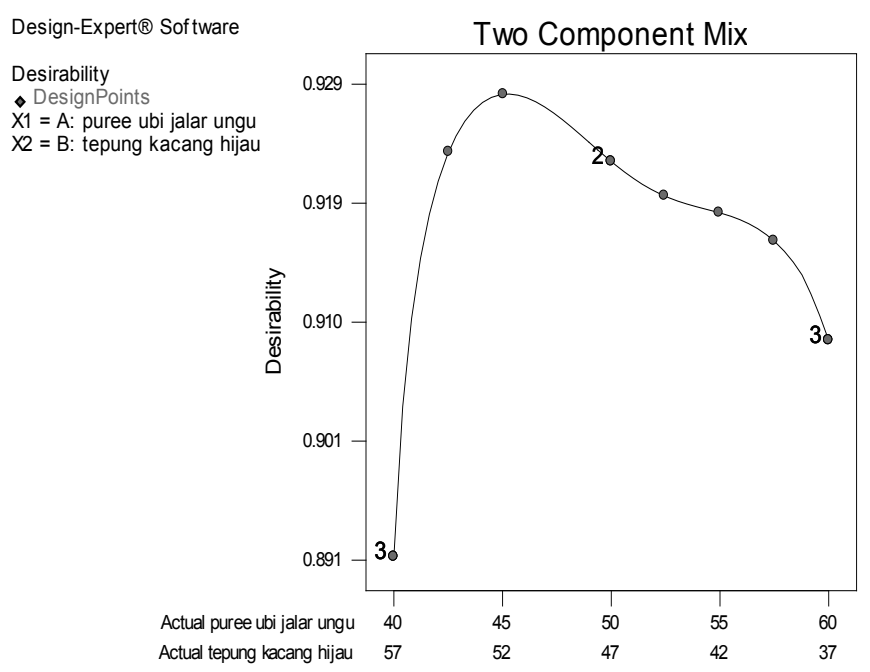

Gambar 2. Grafik desirability pada optimasi formulasi pasta ubi jalar ungu

\section{Verifikasi}

Pada tahap verifikasi formula optimum nilai respon aktual dibandingkan dengan prediksi respon yang dihasilkan. Hasil analisis menunjukkan bahwa prediksi nilai respon dengan nilai aktual menunjukkan hasil yang berdekatan nilainya. Nilai aktual yang diperoleh untuk respon kekenyalan berada pada rentang confident interval, yaitu sebesar 2,29 mm. Nilai aktual respon cohesiveness adalah 0,38 dan kapasitas antioksidan sebesar $20,59 \%$ berada pada rentang prediction interval. Adapun nilai respon warna, KKP, dan kandungan antosianin, masing-masing $333,48{ }^{\circ} \mathrm{H}, 17,62 \%$ dan 42,42 $\mathrm{mg} / \mathrm{L}$ berada pada rentang confident interval dan prediction interval (Tabel 5).
Tabel 5. Prediksi dan hasil verifikasi nilai respon formula optimum hasil optimasi

\begin{tabular}{lcccc}
\hline Respon & Prediksi & $\begin{array}{c}\text { Nilai } \\
\text { aktual }\end{array}$ & $\begin{array}{c}95 \% \text { Confident } \\
\text { interval }\end{array}$ & $\begin{array}{c}95 \% \\
\text { Prediction } \\
\text { interval }\end{array}$ \\
\hline Kekenyalan (mm) & 2,30 & 2,29 & $1,71-2,90$ & $0,4-4,20$ \\
Cohesiveness & 0,43 & 0,38 & $0,4-0,47$ & $0,32-0,54$ \\
Warna (H) & 335,59 & 333,48 & $332,89-338,29$ & $326,97-344,21$ \\
KKP (\%) & 16,74 & 17,62 & $14,15-19,33$ & $8,46-25,02$ \\
Kapasitas antioksidan & 42,61 & 20,59 & $34,81-50,41$ & $17,68-67,54$ \\
$(\%)$ & & & & \\
Kandungan antosianin & 46,16 & 42,42 & $38,72-53,59$ & $32,78-59,54$ \\
(mg/L) & & & & \\
\hline
\end{tabular}

\section{Struktur Mikroskopik Pasta}

Analisis profil produk menggunakan SEM dilakukan terhadap produk pasta ubi jalar ungu matang. Hasil analisis menunjukkan bahwa pasta dengan penggunaan puree ubi jalar ungu pada kisaran $50-60 \%$ di dalam formula pembentukan matrik protein pati masih sangat lemah (Gambar 3a,b,c,d,e). Pada gambar dengan perbesaran 500 kali, permukaan pasta tampak berlipat-lipat, bergelombang, tidak rata, dan terlihat butiran-butiran granula pati. Sedangkan pada gambar dengan perbesaran 2500 kali tampak granula pati yang berbentuk butiran (bulat) yang terpisah-pisah. Pada pasta dengan komposisi puree ubi jalar ungu 60\% granula-granula pati yang terpisah-pisah tampak dengan jelas (Gambar 3a).

Pada pasta matang dengan porsi puree ubi jalar ungu 40-45,04\% di dalam formula sudah tampak terbentuk matrik protein pati (Gambar 3f, g, dan h). Pada komposisi puree ubi jalar ungu 45,04\% granula pati yang terpisah sudah semakin sedikit tampak pada gambar dan tekstur permukaan pasta tampak lebih kompak. Walau demikian, pada perbesaran 2500 kali butiran granula pati masih tampak ada yang terpisah dan tidak terperangkap dalam matrik protein pati. Pada komposisi puree ubi jalar ungu 40\% tekstur permukaan tampak paling kompak dibandingkan dengan pasta pada rasio ubi jalar lainnya (Gambar 3h). Pada gambar dengan perbesaran 500x, permukaan pasta tampak paling halus dibandingkan dengan pasta pada porsi ubi jalar ungu lainnya. Granula pati yang tampak sebagai butiran-butiran bulat tidak tampak karena sudah terperangkap di dalam matrik protein. Pada gambar dengan perbesaran 2500 kali, butiran-butiran granula pati tidak nampak pula. Dengan rasio puree ubi jalar ungu yang semakin kecil, maka rasio tepung kacang hijau dalam formula semakin besar, dan kandungan protein dalam formula akan semakin besar pula. Pembentukan matrik protein pati mempengaruhi keterlibatan pati dalam proses pemasakan, yaitu dengan mengurangi akses air ke dalam pati, mengganggu pengembangan granula pati, dan mengakibatkan berkurangnya kelarutan amilosa, serta menghasilkan film 
yang lebih resisten pada permukaan pasta. Hal ini juga menyebabkan terjadinya peningkatan nilai kekokohan pasta (Fiorda dkk., 2013).

Penelitian sebelumnya pada pasta ubi jalar yang diformulasi dari tepung ubi jalar, tepung terigu, tepung tapioka, dan ditambah sumber protein dari tepung kedelai tanpa lemak dan tepung ikan menunjukkan profil tekstur yang tidak kompak dari hasil analisis menggunakan SEM. Pada perbesaran 2500 kali granula pati tampak terlihat jelas dan terpisah-pisah dimana pemisahan granula serta banyaknya granula yang terlihat pada gambar tampak semakin jelas dan banyak pada produk dengan konsentrasi sumber protein yang semakin kecil (Gopalakrishnan dkk., 2011).

Kekokohan pasta tersebut dapat terlihat dari nilai kekenyalan, cohesiveness, dan KKP. Hasil analisis menunjukkan bahwa nilai kekenyalan dan cohesiveness semakin rendah, dan nilai KKP yang semakin tinggi dengan semakin tingginya komposisi puree ubi jalar ungu di dalam formula.
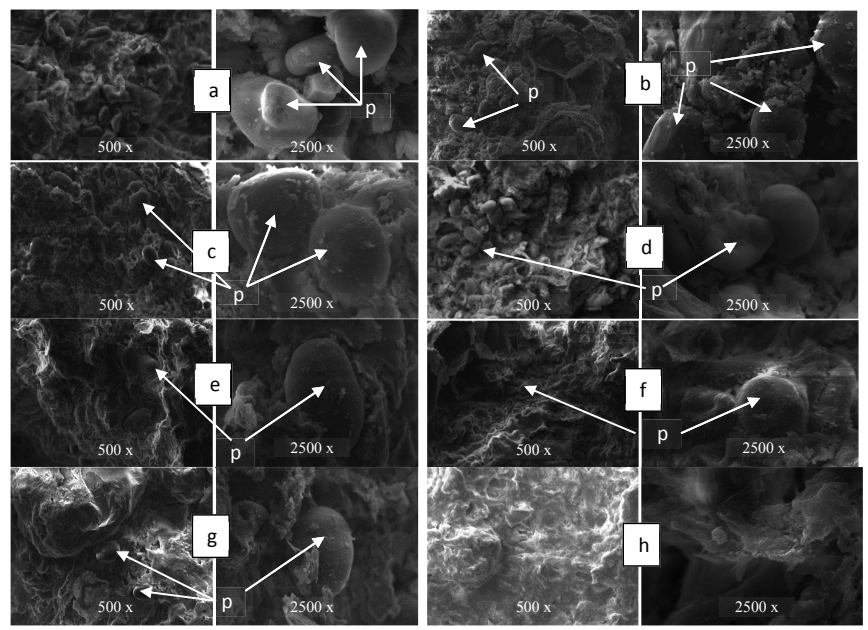

Gambar 3. Struktur mikroskopik pasta ubi jalar ungu matang dengan menggunakan SEM pada perbesaran 500 kali dan 2500 kali dengan komposisi a) $60 \%$; b) $57,48 \%$; c) pasta $54,96 \%$; d) $52,44 \%$; e) $50 \%$; f) $45,04 \%$; g) $42,52 \%$; h) $40 \%$; tanda panah p) pati

\section{KESIMPULAN}

Komposisi optimal puree ubi jalar ungu dengan tepung kacang hijau dalam formula pasta ubi jalar ungu untuk menghasilkan produk dengan karakteristik fisik yang baik dan memiliki nilai fungsional yang baik adalah 45,25\% puree ubi jalar ungu dan tepung kacang hijau 51,75\%. Pada komposisi tersebut dihasilkan pasta ubi jalar ungu dengan karakteristik yaitu kekenyalan 2,29 mm, cohesiveness 0,38, KKP 17,62\%, warna 333,48, IC50 20,59\%, dan kandungan antosianin 42,42 mg/L. Dari segi mikroskopik, pasta ubi jalar ungu matang dengan rasio puree ubi jalar ungu di bawah $50 \%$ sudah menunjukkan adanya struktur yang kompak pada penampakan teksturnya, sehingga menghasilkan nilai KKP yang rendah.

\section{UCAPAN TERIMA KASIH}

Ucapan terima kasih disampaikan kepada Badan Penelitian dan Pengembangan Pertanian, Kementerian Pertanian atas dana penelitian bagi penyelesaian penelitian petugas belajar lingkup Badan Penelitian dan Pengembangan Pertanian.

\section{DAFTAR PUSTAKA}

Alighourchi,H. dan Mohsen, B. (2009). Some physicochemical characteristics and degradation kinetic of anthocyanin of reconstituted pomegranate juice during storage. Journal of Food Engineering 90: 179-185.

Fiorda, F.A., Manoel, S.S. Jr, Flavio, AdS., Maria, V.E.G. dan Luciana, R.F.S. (2013). Microstructure, texture and color of gluten-free pasta made with amaranth flour, cassava starch and cassava bagasse. Food Science and Technology 54: 132-138.

Gopalakrishnan, J., Menon, R., Padmaja, G., Sajeev, M.S. dan Moorthy, S.N. (2011). Nutritional and functional characteristics of protein fortified pasta from sweet potato. Food and Nutrition Science 2: 944-955.

Ho, M.T. dan Athapol, N. (2011). Physiochemical properties of sweet potato and mung bean starch and their blends for noodle production. Journal of Food Processing and Technology 2: 1-9.

Larossa, V., Lorenzo, G., Zariztky, N. dan Calivano, A. (2013). Optimization of rheological properties of gluten-free pasta dough using mixture design. Journal of Cereal Science 57: 520-526.

Limroongreungrat, K. dan Huang, Y. (2007). Pasta products made from sweetpotato fortified with soy protein. Food Science and Technology 40: 200-206.

Lucisano, M., Cappa, C., Fongaro, L. dan Mariotti, M. (2012). Characterisation of gluten free-pasta through conventional and innovative methode: Evaluation of the cooking behaviour. Journal of Cereal Science 56: 667-675.

Marti, A. dan Pagani, M.A. (2013). What can play the role of gluten in gluten free pasta. Review. Trend in Food Science and Technology 31: 63-71. 
Susanna, S. dan Prabashankar, P. (2013). A study on development of gluten free pasta and its biochemical and immunological validation. Food Science and Technology 50: 613-621.
Yasni, S., Widowati, S., Agustinisari, I., Fonna, Z. dan Danuarsa (2009). Pemanfaatan Ubi Jalar Ungu sebagai Bahan Produk Pangan Fungsional. Ringkasan Eksekutif Hasil-hasil Penelitian. Kerja Sama Kemitraan Penelitian Pertanian dengan Perguruan Tinggi. 